\title{
Li Tang, Dietmar W. Winkler (eds). Winds of Jingjiao: Studies on Syriac Christianity in China and Central Asia
}

\section{Christelle Jullien}

\section{(2) OpenEdition \\ 1 Journals}

\section{Édition électronique}

URL : http://journals.openedition.org/abstractairanica/44355

DOI : 10.4000/abstractairanica.44355

ISBN : 1961-960X

ISSN : 1961-960X

Éditeur :

CNRS (UMR 7528 Mondes iraniens et indiens), Éditions de l'IFRI

Référence électronique

Christelle Jullien, « Li Tang, Dietmar W. Winkler (eds). Winds of Jingjiao: Studies on Syriac Christianity in China and Central Asia », Abstracta Iranica [En ligne], Volume 37-38-39| 2018, document 20, mis en ligne le 30 décembre 2018, consulté le 28 septembre 2020. URL : http://journals.openedition.org/ abstractairanica/44355 ; DOI : https://doi.org/10.4000/abstractairanica.44355

Ce document a été généré automatiquement le 28 septembre 2020.

Tous droits réservés 


\title{
Li Tang, Dietmar W. Winkler (eds). Winds of Jingjiao: Studies on Syriac Christianity in China and Central Asia
}

\author{
Christelle Jullien
}

\section{RÉFÉRENCE}

Li Tang, Dietmar W. Winkler (eds). Winds of Jingjiao: Studies on Syriac Christianity in China and Central Asia. Wien: LIT Verlag, 2016, 448 p. (Orientalia - Patristica - Ecumenica 9), ISBN 978-3643907547.

1 À partir de la documentation connue en provenance d'Asie centrale et de la Chine (stèle de Xi'an, manuscrits de Dunhuang et de Qara-Qoto, nombreuses pierres tombales et fragments syriaques), cet ouvrage revisite l'histoire du christianisme syriaque oriental, appelé Jingjiao en chinois, dans cette aire géographique, de l'époque de la dynastie Tang jusqu'à la période mongole. Vingt-quatre articles partagent le volume, subdivisés en trois rubriques: manuscrits et inscriptions; perspectives historiques; traditions liturgiques et théologiques. Parmi les études sur les matériaux mêmes, on notera : D. A. Johnson sur les croix à inscriptions syriaques du centre et du sud-ouest de la Chine («Syriac Crosses in Central and Southwest China», p. 41-62); E. Hunter sur les sanctoraux de Turfān («Commemorating the Saints at Turfan», p. 89-104); de nouvelles pierres gravées retrouvées à Tashkent, Penjikent et Ashgabat par M. Dickens («More Gravestones in Syriac Script from Tashkent, Panjikent \& Ashgabat», p. 105-130). Dans la seconde section, F. de Blois effectue une analyse sur les computs calendaires ( «Al-Bayrūnī - The Twelve Apostles and the Twelve Months of the Julian Year », p. 155-160); A. Platt sur les déploiements missionnaires de l'Église syroorientale sous le patriarcat de Timothée $\mathrm{I}^{\mathrm{er}}$ ("Changing Mission at Home and Abroad : Catholico Timothy I and the Church of the East in the Early Abbasid period ", p. 161-182) ; S. F. Johnson sur les perceptions géographiques de l'Église d'Orient (« The Westwardness of Things : Literary Geography and the Church of the East », p. 183-202) 
et D. Wilmshurst sur la juridiction ecclésiastique du Bēth-Sināyē («Beth Sinaye : A Typical East Syrian Ecclesiastical Province?», p. 253-266) ; K. Parry sur les relations inter-communautaires entre chrétiens melkites et syro-orientaux (Byzantine-Rite Christians (Melkites) in Central Asia and China and Their Contacts with the Church of the East », p. 203-220) et Y. Wang sur le clergé syro-oriental dans le royaume ouigghour de Ganzhou («Priests of Jingjiao in the Xizhou Uighur Kingdom (Five Dynasties - The Early Song Dynasty) », p. 333-348). Enfin dans la dernière partie, S. N. C. Lieu réalise un important travail sur le vocabulaire théologique des textes chrétiens d'Asie centrale et de Chine («Lost in Transcription? -The Theological Vocabulary of Christian Texts in Central Asia and China », p. 339-366) ; Z. Li examine un cas intéressant d'acculturation des chrétiens syro-perses à travers l'étude d'adaptations littéraires («Über die Enkulturation der persisch-syrischen Christen im Tangzeitlichen China -Am Beispiel der abgewandelten Form der „Zehn Gebote“ im „Buch über Jesus den Messias“», p. 367-386); deux autres contributions ont trait aux sacrements (A. Royel, "The Sacraments of the Assyrian Church of the East », p. 387-406), et à des questions d'influences orientales sur le christianisme dit nestorien: D. W. Winkler étudie les influences des moines de Chine sur la théologie sacramentaire des chrétiens syriaques orientaux, «Theological Transfer: How did Monks from China influence East Syriac Sacramental Theology?», p. 407-418) et D. Zhu la transmission de notions du bouddhisme dans le christianisme syro-oriental (« Ying/Nirmāṇa: A Case Study on the Translatability of Buddhism into Jingjiao », p. 419-434). Un index détaillé vient clore un ouvrage bien pensé et nourri - un titre désormais incontournable des bibliographies sur l'Asie centrale et l'histoire du christianisme oriental.

\section{AUTEURS}

\section{CHRISTELLE JULLIEN}

CNRS, Mondes iranien et indien, Paris 